British Politics (2006) 1, 367-396. doi:10.1057/palgrave.bp.4200028

\title{
'This is What Democracy Looks Like': New Labour's Blind Spot and Peripheral Vision
}

\author{
David Judge \\ University of Strathclyde, Glasgow G1 1XQ, UK. \\ E-mail: d.judge@strath.ac.uk
}

New Labour in government since 1997 has been roundly criticized for not possessing a clear, coherent and consistent democratic vision. The absence of such a grand vision has resulted, from this critical perspective, in an absence of 'joined-up' thinking about democracy in an evolving multi-level state. Tensions have been all too apparent between the government's desire to exert central direction manifested in its most pathological form as 'control freakery' - and its democratising initiatives derived from 'third-way' obsessions with 'decentralising', 'empowering' and 'enabling'. The purpose of this article is to examine why New Labour displayed such apparently impaired democratic vision and why it appeared incapable of conceiving of democratic reform 'in the round'. This article seeks to explain these apparent paradoxes, however, through utilising the notion of 'macular degeneration'. In this analysis, the perceived democratic blind spot of New Labour at Westminster is connected to a democratic peripheral vision, which has envisaged innovative participatory and decentred initiatives in governance beyond Westminster.

Keywords: British politics; devolution; executive-legislative relations; parliamentary democracy; participation; Westminster model

\section{'This is What Democracy Looks Like'}

These words have reverberated around the streets of major cities throughout the world in the 21 st century, as demonstrators and protestors have railed against a variety of perceived injustices perpetrated by individual governments and global capitalismalike. It was perhaps of no surprise, therefore, to hear these very words echoing through the genteel cobbled streets of Edinburgh as demonstrators fought sporadic battles with riot police on the occasion of the G8 summit in Scotland in July 2005 (see The Herald, 5 July 2005). Yet the images of riots and mass demonstrations were not the images normally associated, in the minds of British politicians and the public, with the workings of 'their democracy'. Indeed, within a few days of the mass demonstrations in Edinburgh, and after the suicide bombings in London on 7 July, the UK's 
prime minister, MPs of all parties, press commentators, and members of the public alike, were quick to invoke a vision of 'our democracy' which was starkly counterposed to the images of mass murder on and below the streets of London, and to the mass protests on and around the streets of Scottish cities during the course of the G8 summit. What democracy looked like in this vision was a peaceful process of deliberation and compromise associated with parliamentary democracy. As the then Home Secretary, Charles Clarke, informed the House of Commons (HC) on the day of the London bombings: It is encouraging that right across every fragment of opinion in the House, we say that our democratic methods are the way to prevail and that we are determined to do whatever we must in order to ensure that those who seek to destroy that democracy are unable to carry out what they would wish (HC Debates, 7 July 2005, vol. 436, col. 469).

\section{But what were these 'Democratic Methods'?}

The vision of democracy subscribed to in the official statements of the New Labour government was clear and orthodox. In essence it was a simple and unmediated perspective of the Westminster model. Indeed, the continuing centrality of that model had been reaffirmed throughout Labour's period in office after 1997 and was captured succinctly in the official statement:

The United Kingdom is a Parliamentary democracy. Sovereignty rests with the Crown in Parliament. Law making rests with the tripartite sovereignty of Crown in both Houses of Parliament. In practice, the powers of the three parts are uneven. The House of Commons [has long] been established as the pre-eminent constitutional authority within the UK. The Government is formed by the Party which can command the support of the House of Commons. The Party which secures a majority [at a General Election] has the right to forma Government and, subject to sustaining its Parliamentary majority, to carry through the programme set out in its election Manifesto. Ministers are continuously accountable to the House of Commons through debates and votes; a process formalised and fortified by the role of the nonGovernment Parties in forming an Opposition, with the largest nonGovernment Party occupying the position of Official Opposition. This constitutional framework, founded on the pre-eminence of the House of Commons, has provided Britain with effective democratic Government and accountability for more than a century, and few would wish to change it (Cm5291, 2001, paras 13-17).

It was no coincidence that the word 'effective' preceded the word 'democratic' in the phrase 'effective democratic government'. Historically representative 
government in the UK has been conceived and functioned as a means of legitimating executive power (see Judge, 1993, 2; 2005, 28). An executive centric state has been justified in terms of a legislative-centric theory of parliamentary sovereignty. The practical pre-eminence of the executive in the UK state has thus been founded upon the theoretical 'pre-eminence of the House of Commons'. This has been the central paradox of the parliamentary state and has been routinely noted as the central dilemma confronting New Labour's programme of constitutional reform.

\section{Westminster at the Centre: Loss of Central Vision}

In the Westminster model the authority of government stems from its majoritarian position in the House of Commons. This majoritarian position marks the focal point of the state system. It is literally 'the centre' of government. However, from this position the vision of government is afflicted by a particular form of macular degeneration.1 A 'blind spot' develops out of the conjunction of the two institutions 'parliament' and 'government' into a blurred vision of 'parliamentary government'. In this conjunction, the House of Commons is located at the centre of the political executive's vision, yet superimposed upon, and ultimately obscuring, the view of parliament itself is the image of 'strong government'. In this manner, parliament and government are merged into a single, symbiotic image — of parliamentary government. From this mono-focal perspective, the political executive loses sight of parliament as a discrete institution; and comes to see itself as simply the preeminent, majoritarian element of the representative lower House. In this sense, as Labour MP Graham Allen $(2003,20)$ notes, the House of Commons has become, in effect, a 'House of Government'. Another Labour MP, Tony Wright $(2004,867)$, reinforces this view: 'There is a fundamental fact that in Britain, the executive is particularly strong and Parliament commensurately weak. Behind the constitutional rhetoric about the sovereignty of Parliament there lies the reality of executive dominance in a political system which concentrates power rather than divides it'.

In its acute form, governmental macular degeneration has revealed the symptoms of 'elective dictatorship'. The phrase was popularized by Lord Hailsham $(1978,22)$ in his analysis of a system in which 'parliament is omnipotent, and since the government can rely on a majority in the Commons there are few effective limits to the powers of a government $y$ Practically no other civilised country has invested its representatives with such unlimited authority' (ibid., 101). If anything, this position has been perceived to have become even more acute under New Labour governments (see, for example, Power Inquiry, 2006, 128-135). 
Certainly with majorities of 178 and 167 after the 1997 and 2001 elections the policy preferences of government and the legislative outputs of parliament were unlikely to diverge to any significant degree. For a government elected on a 'guiding rule not to promise what we cannot deliver; and to deliver what we promise' (Labour Party, 1997, 2), 'getting things done' and 'driving forward reform, building lasting change' (Blair quoted in Ludlam, 2004, 1) was at the heart of a continuing commitment to 'British renewal' (Labour Party, 2001, 3). Here was a government which proclaimed that it 'made decisions because they were right - not because they were destined to be popular' (ibid., 2005, 9); and made a virtue of making a 'covenant' (ibid., 1997, 1) with the electorate to be accountable for its record in government.

If New Labour's priority was thus to be afforded to 'delivery', its focus was upon efficiency and modernisation in government to achieve this objective. If the government already knew it was right, it did not wish to be impeded unnecessarily by other institutions, or people, telling it that it was not. Successive electoral victories in 1997, 2001 and 2005 confirmed to the government, in its own collective mind at least, that the electorate had acknowledged that it was right; and the electoral system had provided the necessary majorities in parliament to confirm this 'rightness'. In this sense, the majoritarianism of the parliamentary system was not seen as a problem by New Labour governments, just as it had not been by any of its post-war predecessors. In this respect, New Labour governments after 1997 simply displayed the same symptoms of macular degeneration that had afflicted all post-war governments. For all governments, single party majoritarianism was not seen as a failing, but instead was deemed to be a virtue, of parliamentary democracy in the UK. What prevented single party majoritarianism from tipping over into single party dictatorship, in this view, was the chain of accountability linking governments to elected representatives in parliament and through themto the electorate at large.

Beyond Westminster, however, the degenerative symptoms afflicting the central vision of the executive were widely perceived. The related pathologies - of executive mentality; conjoined party, legislative and executive leadership roles; the nature of party competition, and the executive's risk-aversion to the media - cumulated in the inversion of the idealised serial flow of accountability at the heart of the Westminster model and left a democratic blind spot at the centre of UK government.

\section{Executive Mentality}

An 'executive mentality' has long been observed by commentators (see Judge, 1981, 1990, 1993, 2005; Flinders, 2002). At one level it is ascribed to an instrumental logic of government. Reduced to its simplest formulation this 
logic assumes that all governments wish to implement their policy pledges as efficiently and as expeditiously as possible. What remains unclear, however, is why 'efficiency' would be privileged by ministers over 'legitimacy' derived from rigorous scrutiny? After all, the very same politicians, as shadow ministers, were only too aware of the democratic pathologies associated with 'efficiency' and 'strength' of government.

One partial explanation is to be found in analyses, which focus on the personal characteristics and predilections of prime ministers over the past 25 years, and their preferences for 'authoritarian populism' (Mrs Thatcher) or 'control freakery' (Mr Blair). The problem with this argument is to explain why the UK historically has been so unfortunate in its choice of prime ministers, as 'authoritarian' or 'dictatorial' tendencies had been ascribed to PMs long before Mrs Thatcher and Mr Blair. Low (1904, 158), for example, identified Pitt, Peel, Palmerston, Disraeli and Gladstone as 'coming near' to being dictators. Bogdanor $(2003,10)$ updated this list by noting that Balfour, Lloyd George, Neville Chamberlain, Churchill, Macmillan, Wilson and Heath had allegedly taken upon themselves, at various stages in their respective relationships with their own cabinet colleagues, powers 'not inferior to that of a dictator'. Such an extensive list suggests that explanations revolving around personality or individual agency are insufficient in themselves in explaining why a universal executive mentality develops in the UK. In which case, other structural and institutional explanations have to be examined as well. What becomes immediately apparent is that UK governments become locked into common modes, or trajectories, of behaviour and working routines (irrespective of party composition or the personal characteristics of leaders). These routines reflect the inter-institutional relationships at the heart of the Westminster model. In this sense, 'new institutional' notions of path dependency provide analytical purchase in trying to explain executive macular degeneration (see Judge, 2005, 9-15). The paradox is that 'the path' is determined beyond the executive itself. The basic institutional features of the Westminster model were captured in the government's formal statement noted above: the government is drawn from the House of Commons and derives its authority as the largest party in the House; and as long as it sustains this majority support the government has the right to implement its policy programme, subject to the scrutiny of, and its accountability to, elected representatives. Yet this simple institutional model, in sketching a serial flow of responsibility which links the governed to their governors, obscures a far more complex portrait of an interwoven institutional chain of elections, parties, legislature and executive. In this chain, the institutional characteristics of the executive are 'determined' successively and cumulatively by linkages of responsibility. Thus, if New Labour in government has obtained a reputation for 'control freakery', despite its pronouncements in opposition in favour of modernisation and democratisation, it is because of the 
institutional matrix within which it has to operate. It is worthwhile, therefore, disentangling the institutional strands of this matrix.

The first requirement of government is to win elections. In this respect, the Labour party has successfully transformed itself from its position, in the 1980s and early 1990s, as an electoral liability to one of electoral ascendancy by 2005 - with New Labour winning three successive general elections and with its leader becoming the longest serving Labour PM. This transformation was effected both through ideological reorientation and an internal modernisation of the party's organisational structure. Two parallel organisational reforms were undertaken: first, the party-trade union link was loosened; and, second, the leader's autonomy from members was increased (see Quinn, 2004; Russell, 2005). Cumulatively in opposition there was a drift towards 'a more powerful central apparatus, greater organisational centralisation, more concentrated patterns of authority, and tauter discipline' (Shaw, 2004, 67). In part, the internal demand for greater discipline and coherence within the party reflected its external relationships with the electorate generally and also with a wider media culture specifically. This was a rapidly changing media culture in the 1990s and one characterised by: increased fragmentation and pluralism of media outlets; the advent of ' 24 hour news'; the changing conventions of political coverage with disputation, rumour, and non-deference the preferred style — and with 'laser journalism' premised upon a belief that politicians were 'the liars-in-chief, the gatekeepers of vaults of dirty big secrets that wait for the deployment of journalistic diligence and courage to be discovered' (John Lloyd quoted in Bartle, 2005, 130). In particular, as Cowley observes $(2005,10)$ :

Few members of the British media follow US President Herbert Hoover's injunction that 'honest differences of views and honest debate are not disunity. They are the vital process of policy-making among free men'. Deviations fromthe party line are instead always pounced upon as evidence of disunity.

Thus, as Tony Blair noted early in his premiership, 'ill-discipline allowed us to be painted as extremist, out of touch and divided. It helped keep us out of power for 18 years' (The Independent, 20 November 1998). If the relationship between New Labour and the media was defined before entry into office, the pathologies of this relationship were ultimately to become intertwined with the pathologies of the institutional relationship between legislature and executive. The obsession in the media with 'splits' reflected an assumption of an adversarial, zero-sum political culture, and, in turn, came not simply to mirror but also to entrench that adversarial culture. Before examining this latter relationship it should be noted that even after its ideological transmogrification and organisational renewal New Labour remained an ideological 'coalition' of remnants of 'Old Labour', social democratic revisionists, modernisers, and 
born-again 'third way-ers'. That these fractions continued to coalesce in a single party had much to do with the nature of the UK's first-past-the-post electoral system that rewarded the two major parties with disproportionate representation in the Commons, and routinely, disproportionate majorities for the governing party.

The style of electoral politics reflected a broader, national style of politics - one that was characterized by Finer over 30 years ago as 'adversary politics'. Finer was in no doubt that this style was the 'fruit of the two-party system, and this itself is the consequence of our electoral system' (1975, ix). The essence of this system was a 'stand-up fight' with 'rival teams of politicians in open contention which goes on before an election, during an election, and - above all - continues after the election, in the form of continuous polemic across the floor of the Commons where a powerless Opposition confronts an all-powerful Government' (ibid., 3). The adversarial system, therefore, not only affects the style of electoral campaigning and reporting, but also impacts upon the organisation of parties and the nature of party competition (see Aspinwall, 2004, 4; McHugh and Parvin, 2005, 20), as well as influencing the institutional relationship between parliament and the executive.

\section{Executive and Legislature}

Two basic features characterise the relationship between the executive and the legislature in the UK. The first is that the members of the political executive are drawn from the legislature. In other words, holding executive office and being a member of parliament (overwhelmingly an elected member) are coterminous positions. Second, political leadership positions in the executive are synonymous with leadership positions in the majority party. As Weir and Beetham (1999, 372) observe: 'Parliament, therefore, has little distinct life or identity of its own, separate from government and party'. This conjunction of institutional leadership roles - whereby leaders of the majority party simultaneously hold parliamentary and executive leadership roles (neatly encapsulated in the fact that the formal parliamentary office of Leader of the House of Commons is occupied by a cabinet minister) - means that discrete party, parliamentary and executive norms are transmuted into an overarching 'executive mentality'. As the House of Commons' Modernisation Committee noted: 'Ministers are also Members of Parliament, and are sustained in office by Parliament' and that 'party loyalty and organization structure the way in which Parliament and its institutions work' (HC 300, 2000, para 9). This conjunction (and confusion) was summarised by one reformist, former Leader of the House Robin Cook (2003, 153): 
Most MPs are deeply ambivalent about their primary role. MPs usually recognise that somewhere in their job description is a responsibility to protect the privileges and independence of Parliament. At the same time all MPs are elected on a party ticket and came to Westminster not as independents but as partisans. This dual identity of MPs ensures a constant struggle between the perception of the role of Parliament and their sense of belonging to a party fraction.

Routinely, the latter perception overrides the former. The norms of party loyalty are evident in a series of surveys and academic studies (see, for example, Searing, 1994; Rush, 2001; Cowley, 2002, 2005). While these norms are not absolutes, it remains the case that the 'overwhelming desire on the part of the vast majority [is] not to do anything that might make their party appear divided' (Cowley, 2002, 182). Certainly the risk-aversion of modern executives in exposing themselves to hostile partisan and media criticism and 'political embarrassment' has led them to prioritise party loyalty. But it also engenders an insularity and secretiveness at the core of the relationship between the executive and the legislature. When linked to the adversarial nature of parliamentary discourse and procedures, the prioritisation of party loyalty in the face of perceived threats of hostile, and potentially malicious, scrutiny from opposition parties and media alike - the executive retreats into a 'bunker mentality' wherein: 'we are not going to tell [MPs] more than we can about what is going to discredit us'. These words were certainly issued by a Labour politician, and certainly could have been associated with New Labour, but, in fact, they are the words of James Callaghan some 25 years before Tony Blair came to power (Cmnd 5104, 1972).

\section{Inversion of Accountability}

Risk-aversion, in the form of sensitivity to partisan embarrassment and fear of political 'discrediting', continues to underpin the normative system of the modern political executive. Although the revised Ministerial Code emphasises that 'Ministers have a duty to Parliament to account, and be held to account, for the policies, decision and actions of their department and agencies' (Cabinet Office, 2005a, 1.5 b), and that they should be 'as open as possible with Parliament and the public' (ibid., 1.5d), the Code also propounds certain 'principles' which should guide the interactions of members of the executive with parliament. Ironically these principles are elaborated explicitly for only the most junior members of the executive, Parliamentary Private Secretaries, who are clearly advised that they are 'expected to support the Government in all divisions' and 'should avoid associating themselves with recommendations critical or embarrassing to the Government' (ibid., 2.9). Ministers themselves 
are simply cautioned that they are subject to the conventions of ministerial responsibility. Collective responsibility requires that 'Ministers should be able to express their views frankly in the expectation that they can argue freely in private while maintaining a united front when decisions have been reached. This in turn requires that the privacy of opinions expressed in cabinet and ministerial committees should be maintained' (ibid., 6.17). The expectation is that 'once a decision has been announced, it should be accepted without question or criticism', and certainly ministers are expected to 'avoid criticism of government policies' (ibid., 4.6). In practice, however, such expectations often remained unfulfilled. Even the deputy prime minister, John Prescott, was accused of embarrassing the government in December 2005 in his public criticismof the government's education white paper (see The Sunday Telegraph, 18 December 2005, 4; The Evening Standard, 19 December 2005, 2; news.bbc.co.uk/1/hi/uk_politics/4539074.stm).

Similarly the constitutional convention of individual ministerial responsibility has provided 'a strong determinant of the structural development of administrative organisation and therefore the style of government' (Radcliffe, 1991, 29). Notions of individual ministerial responsibility have served not only to operationalise the external requirements of accountability, but have also served to sustain the internal organisational requirements of political control within departments (see Judge, 2005, 120-123). Significantly, the 'accountability' of departmental ministers to parliament, and the cascaded relationships within departments stemming from this external accountability, have been based upon 'normal rules' of confidentiality pertaining to civil service advice (Cabinet Office, 2005a, para 2.14). In turn, these 'normal' internal rules have come to prescribe the external relationship between departments and Parliament: 'Civil servants should not without authority disclose official information which has been communicated in confidence within the Administration' (Cabinet Office, 1999, para 10).2

Thus, a central paradox of the parliamentary state in the UK is the fact that the constitutional logic of the convention of ministerial responsibility - of executive openness and accountability — is inverted by a more immediate, pragmatic, political logic that serves to insulate executives from accountability (see Judge, 1993, 2005) and ultimately to 'eviscerate the participatory claims of reformers' (Flinders, 2002, 27). In this inversion of accountability, the precipitants of executive macular degeneration are to be found.

\section{Parliamentary Reform: Blind spot at the Centre of Parliamentary Democracy}

When assessing New Labour's programme of parliamentary reform since 1997 it is important, as Tony Wright $(2004,868)$ counsels, to take into account the 
'underlying reality' of executive dominance in a parliamentary system based upon the electoral competition of disciplined political parties. This is also a reality which blurs the notions of parliamentary government and parliamentary democracy, and in which reforms to enhance the capacities of government are often misperceived as enhancements of democracy.

For all that New Labour in office had an impressive record of reformist endeavour in Westminster (see Kelso, 2006), the modernising agenda outlined in the 1997 manifesto remained unfulfilled by the time of the 2005 general election. Even Labour's own manifesto in 2005 acknowledged that there was still a pressing need to 'continue to support reforms that improve parliamentary accountability and scrutiny' (Labour party 2005, 111). Indeed, it could hardly argue otherwise. A broad consensus of opinion both inside and outside of Westminster was in no doubt that further reform was necessary. In its partisan guise, this sentiment was expressed in the Conservative manifesto thus:

Under Mr Blair the way we are governed has become less accountable, more complex and, ultimately, less democratic. The House of Commons has been steadily undermined, and proper reform of the House of Lords has been repeatedly promised but never delivered. The House of Commons needs to be made more capable of standing up to the executive' (Conservative party, 2005, 21).

In a more academic formulation this view found expression in Brazier et al.'s $(2005,78)$ conclusion that: 'despite some improvements, Parliament remains in many ways an inefficient and, some would allege, largely ineffective institution while there have been some important changes in the relationship between the executive and Parliament, it remains clear that the balance of power remains firmly in the lap of the former'. Similarly, in his assessment of the record of New Labour's parliamentary modernisation programme, Tony Wright drew a distinction between 'modernisation as efficiency' - which was 'favoured by governments' and was 'essentially executive-minded' — and 'modernisation as scrutiny' which 'wants to shift the balance between the executive and legislature in significant respects' and which 'is much less attractive to governments' (2004, 869-870). Not surprisingly Wright concluded that the former kind of modernisation had prevailed over the latter (see also House of Commons, 2005a; Kelso, 2006).

Where the 'blind spot' of the New Labour government was most apparent was in the consistency with which it defended the convention of ministerial responsibility - but in a defensive and insular formulation. This formulation was particularly evident in the executive's interactions with select committees. On the one hand, the government committed itself to openness and 
accountability and advised civil servants appearing before select committees that:

The central principle to be followed is that it is the duty of officials to be as helpful as possible to Select Committees. Officials should be as forthcoming as they can in providing information care should be taken to ensure that no information is withheld which would not be exempted if a parallel request were made under the FOI Act (Cabinet Office, 2005b, para 53).

Yet, on the other hand, officials were also counselled that they should:

as far as possible confine their evidence to questions of fact and explanation relating to government policies and actions. Officials should as far as possible avoid being drawn into discussion of the merits of alternative policies where this is politically contentious (ibid., para 55).

The general debilitating effects of this prohibition upon parliamentary scrutiny of executive actions had been apparent since the inception of the select committee system in 1979 (see Judge 1981, 1983, 1993, 2005).More specific and contemporary effects were noted, however, in the contrast between the access to information afforded to the Hutton and Butler Inquiries and that afforded routinely to select committees (HC 446, 2004, para 87). While the House of Commons' Liaison Committee was convinced that it was only 'reasonable to expect that select committees should receive Government co-operation as fully as an inquiry set up by the government itself' (ibid., para 89), the executive's actions continued to confound this reasonable expectation. Thus, despite its undertakings to be as 'forthcoming and helpfulyin providing information' (Cabinet Office, 2005b, para 9), and especially to allow special advisers to appear before select committees (HC 1180-I, 2004, q1; q26; Cabinet Office, $2005 \mathrm{~b}$, para 44), in practice the government continued to display a reluctance to allow open access to 'those at the centre of government who are called on to advise on those public policy issues affecting the whole of government' (HC 690, 2005, para 12). The unwillingness of the Prime Minister in particular to permit key advisers (most notably Lord Birt in late 2005) 3 to give evidence to committees elicited the damning response of the Public Administration Committee:

In refusing to allow its special advisers to appear before the Committee on inquiries which are directly germane to their work, the Government, and No. 10 in particular, has failed to live up to its undertakings. This is hampering, unnecessarily, the ability of Parliament to undertake effective scrutiny (ibid.). 
The exasperation of the chairmen of select committees shone through in the question posed to the PM in his appearance before the Liaison Committee in November 2005:

Parliament is supposed to be the focal point of accountability for ministers and yet we cannot get anything like the volume of information nor the easy access of witnesses that were provided to Hutton and Butler. Can you not see that leads to the impression that if you want to get a proper inquiry you have to go outside Parliament because the Government will not co-operate with its internal inquiries? (HC 709-i, 2005, q9).

Indeed, backbench MPs have often sought information 'outside Parliament' when confronted by executive recalcitrance. This has involved the use of the provisions of both Freedom of Information and Data Protection legislation (see HC 136, 2002, 5-6; House of Commons, 2005b; Brazier et al., 2005, 54-56).

\section{Peripheral Vision: Democracy Beyond Parliament}

\section{The Freedom of Information Act 2000}

In itself, the very fact that the Freedom of Information (FOI) Act 2000 came into force in January 2005 might appear to undermine the contention that the New Labour government continued to display the symptoms of macular degeneration. Indeed, in reviewing the first year of the operation of the Act, Lord Falconer, Secretary of State for Constitutional Affairs, emphasised the point that:

Oppositions talk of freedom of information. They tend to forget that talk when they become governments. We did not. From 1 January 2005, we introduced a legally enforceable freedom of information regime (The Guardian, 31 December 2005).

Lord Falconer went on to state that 'Good government is open government'. Though he also noted that there was a case for the 'legitimate retention of information in order to promote good government in the public interest'. In essence, his argument reflected the orthodoxy of all UK executives: 'It does not promote good government toypublish details of ongoing internal policy discussion where people express their views and advice on the basis it is confidential. Governments of all political stripes need the space to govern for all of the public' (The Guardian, 31 December 2005).

Due praise was afforded to the New Labour government on passing the FOI Act, and in responding to 19,374 FOI requests received by government departments under the Act in its first year (in total 37,849 requests were 
received by 42 government bodies in 2005, see Department of Constitutional Affairs, 2006, 17). Predictably, however, there were concerns about the implementation of the Act and the speed with which requests were processed. Even more predictably, perhaps, there was consternation at the significant limitations upon disclosure of information that remained. Under Section 35 of the 2000 Act, for example, there are class-based exemptions relating to the formulation or development of government policy; ministerial communications; the provision of advice by any of the Law Officers; or the operation of any ministerial private office. In effect, such exemptions left 'control over large tracts of information, much of it exactly the information that the public and press would need to have access to in order to hold government to account, in the hands of ministers' (Oliver, 2003, 167; see also Evans, 2003, 208-214).4

\section{Human Rights Act}

Notions of 'citizenship' link the issues of open government and human rights in the minds of many advocates of increased democratisation in the UK (see Wright, 1994; Evans, 2003, 158-163, 177-180; Oliver, 2003, 160-161, 124-130). In this approach 'individuals are rights bearers as well as citizens in a political community' (Oliver, 2003, 160). Historically, however, the Labour party had subscribed to the view that 'the protection of rights was a matter for Parliament: individual rights were to be won in Parliament and to be secured and preserved there' (Ewing, 1999, 81). In moving from this historic stance, at least one commentator found it 'most remarkable' that 'no leader of New Labour, which had engineered the assault on parliamentary sovereignty which the Human Rights Act (HRA) represented, was prepared to articulate an accepted revised philosophy' (Stevens, 2002, 135). Indeed, it is worth examining the two parts of Stevens' statement sequentially: to determine the extent to which, first, there was an 'assault on parliamentary sovereignty'; and, second, why a revised philosophy would remain unarticulated.

From the outset, New Labour did not seek a frontal assault on parliamentary sovereignty but rather sought to 'deliver a modern reconciliation of the inevitable tension between the democratic right of the majority to exercise political power and the democratic need of individuals and minorities to have their human rights secured' (the then Lord Chancellor Lord Irvine, House of Lords Debates, 3 November 1997, vol. 582, col. 1234). When the needs of the latter conflicted with the requirements of the former (in the form of a majority party exercising political power) then 'reconciliation' was heavily skewed in the former's favour. In fact, the example of New Labour's antiterrorist legislation neatly encapsulated the nature of 'reconciliation' between the exercises of executive power and the human rights of individuals and minorities. 5 
In introducing its human rights legislation the government was adamant that the principle of parliamentary sovereignty had not been infringed. Nonetheless, when introducing the Prevention of Terrorism Bill 2005, the then Home Secretary, Charles Clarke, acknowledged that the HRA had engendered a new, more complex, reality of the relationship between the judiciary, the executive and parliament:

What I do think is that when the Law Lords of this country make a set of criticisms [ruling that section 23 of the Anti-Terrorism Crime and Security Act 2001 was incompatible with the European Convention on Human Rights] about the way that we are operating that is well founded, by a vote of eight to one, it is incumbent on the Government - and I would argue on Parliament - to respond to that and decide how to deal with it (HC Debates, 23 February 2005, vol. 431, col. 346).

What was equally apparent during the passage of New Labour's anti-terrorism measures was that the government did not welcome critical parliamentary 'responses', especially those from the House of Lords, about the unprecedented scope of the powers of the new legislation. Although the government was insistent that the new legislation was 'fully compatible' with the European Convention on Human Rights, it encountered significant and sustained parliamentary opposition in both Houses precisely because of concerns about 'compatibility'. Indeed, so great was the opposition to a proposed clause extending the period of pre-charge detention to 90 days that the New Labour government suffered its first defeats in a vote in the House of Commons in November 2005. What the defeats illustrated were the intertwined and variable interinstitutional interactions between party, legislature, executive and judiciary.

What is of particular importance for present purposes, however, was the response of the Prime Minister to defeat in the House of Commons. Mr Blair's belief, noted earlier, on being right, and its corollary of impatience with parliamentary opposition, was reflected in his linked statements: 'Sometimes it is better to do the right thing and lose, than to win doing the wrong thing'; and ' $[\mathrm{t}]$ he country will think parliament will have behaved in a deeply irresponsible way. I have no doubt about that at all' (quoted in The Guardian, 10 November 2005). This response resonated with an executive mentality, to such a degree that Andrew Rawnsley observed that Mr Blair 'spoke less like a prime minister in a parliamentary system of government and more as an American president might scorn an obstructive Congress' (The Observer, 13 November 2005). In part Mr Blair's sanguine reaction was also based on the partisan calculation that the Conservatives (and Labour rebels) might yet be haunted by their actions in the face of some future terrorist attack. Indeed, the partisan dimension of the development of anti-terrorist measures became more 
pronounced after the two defeats suffered by the government in February 2006 on the Racial and Religious Hatred Bill. The Home Secretary noted that: 'I actually think that what happened was a purely political act by the Conservatives and Liberal Democrats and some of the people on the Labour side to try and deliver a defeat to the government rather than a genuine consideration of the issues' (BBC News, 1 February 2006). The Home Office minister, Paul Goggins, echoed the earlier words of the Prime Minister: 'We have some choices to take in the weeks and months ahead about whether the political objective of the House of Commons is to defeat the government at every possible opportunity or whether it is to get the right policies' (news.bbc.co.uk/1/hi/uk_politics/4668868.stm).

Equally instructive was the response of sections of the media to the Commons defeat. Instead of commending MPs for restraining the wilder excesses of an omnipotent executive (in other words for doing what parliamentarians are routinely criticized for not doing) The Sun newspaper chose to argue that: 'Treacherous MPs betrayed the British people last night by rejecting new laws to combat terror. They ignored the wishes of the vast majority of Britons and humiliated Tony Blair by inflicting his first Commons defeat' (The Sun, 10 November 2005). The Star managed an even more succinct summary of events: 'lame duck Blair was told to quack off last night following his most humiliating defeat'.

\section{Peripheral Vision: Democracy Below the UK Parliament}

While macular degeneration results in reduced central vision, good peripheral vision is generally retained. An analogy can thus be drawn with New Labour's approach to government and democracy 'beyond the centre' in the case of devolution and decentralisation. In The Third Way Giddens argued the case for the 'democratisation of democracy' and that such democratization 'first of all implies decentralisation' (1998, 72). While the 'third way' vision does not deny the need for 'strong government', a 'key challenge of progressive politics' is how to 'use the state as an enabling force, protecting effective communities and voluntary organisations and encouraging their growth to tackle new needs, in partnership as appropriate' (Blair, [1998] 2003). New Labour in 'Third Way mode' is thus 'at ease with establishing a strong range of cross checking institutions at different levels of governance and ensuring that those institutions are open and accountable and capable of working alongside private, voluntary and community interests' (Stoker, 2002, 431). There can be no doubt that New Labour in power has been pro-active, even hyper-active, in pursuing democratisation beyond the centre. 


\section{Devolution}

Devolved government was never likely to involve an institutional year zero, shaking off institutional continuities from the UK system of government, as some hoped (Mitchell, 2004, 35).

Nonetheless, the hopes of 'third way' acolytes within New Labour were rooted in a conviction that: 'The centralisation of decision making in Britain today [was] absurd' (Mandelson and Liddle, 1996, 187). In this sense old continuities had to be fractured as the 'closer politics - and power - is to people, the more chance there is of interaction between them. And that is what democracy is about' (ibid., 197). Here, indeed, was a conception of democracy that was consciously counterposed to the established Westminster model and which was designed to generate, ultimately, an inclusionary and participatory 'new politics'. Yet, this was not a peculiarly New Labour vision as it was shared, especially in Scotland, by a range of other parties and civil society organisations. What was clear, however, was that there was to be an explicit attempt to move away from the adversarial politics of Westminster and to inculcate 'grown-up, civilized' behaviour in Edinburgh (Anne Begg, HC Debates, 13 January 1998, vol. 304, col. 177).

The subsequent intent and achievements of the Labour government should not be underestimated: a Parliament in Scotland and Assemblies in Wales and Northern Ireland were rapidly established (even if the latter was in suspension after October 2002); and the cause of regional government was promoted in the institutional formof the Greater London Authority and the initiation (albeit stuttering and soon stalled) of a process of regional devolution in England. Indeed, within a very short period what was notable was the "normalisation of devolved governance in Scotland and Wales' (Bradbury and Mitchell, 2005, 301). If the term 'normalization' is accepted then overall assessments about 'success' or 'failure' of devolution can be side-stepped here, and all that needs to be remembered in the following discussion is that any serious evaluation of devolution has to be 'nuanced' (Trench, 2004, 1).

What is important to note, however, is that, in the exercise of 'normal' postdevolutionary politics, the symptoms of executive macular degeneration associated with the Westminster model came to be reproduced in mutated form in devolved institutions. The initial clear vision of the 'new politics' showed signs of progressive impairment as a result of the genetic institutional inheritances from the 'old politics'. Clearly, the designers of the new representative institutions in Scotland and Wales consciously sought to inculcate novel values and norms, and to work from an institutional blueprint, that explicitly did not replicate the Westminster model. Yet, in trying to import the values of participation, inclusion, openness and cooperation into the new 
representative institutions in Scotland and Wales, the designers both misread the Westminster model and underestimated the inherent tension between popular inclusion and exclusion in the very nature of representative democracy (see Judge, 2005).

One consequence of this misreading was that the inclusionary vision of democratised Scottish governance became blurred.6 Assessments of the extent to which a new politics based upon a 'participatory ideal' have intruded into Scottish governance have concluded that when 'measured in terms of political power' participatory initiatives associated with the Scottish parliament 'appear more symbolic than effective' (Mitchell, 2004, 39; see also Bonney, 2003). More strikingly, there was a dawning realisation among the more naïve proponents of the 'new politics' that 'in the end, the decisions of the Parliament have to be made by elected representatives' (Bonney, 2003, 467). If notions of representative democracy were once more to be privileged in this manner, the genetic constitutional 'stemcell' from which such notions derived in the first instance - the Westminster model - held the potential to be reproduced in modified form in the devolved institutions.

Indeed, the symptoms of adversarial politics have been apparent in Scotland. Arter $(2003,18)$, for example, concluded that the relationship between the majority Labour-Liberal Democrat coalition that formed the Executive and the leading opposition party, the Scottish National Party, had been 'quintessentially adversarial'. He proceeded to note that this relationship had been sustained by the 'ground rules of the Westminster game'. Hence, the parties in the executive coalition have expected the loyalty of their respective MSPs and have sought to enhance discipline in parliament through intra-party rule changes (see The Sunday Herald, 23 October 2005). Recognition that 'power lies in the coalition at least so long as the coalition acts cohesively' has contributed to a 'remarkable' rarity of Executive defeats by Parliament (Mitchell, 2005, 37); and, overall, the 'tight grip of parties' has been adjudged to have 'reduced the liberating potential of devolution' (Keating, 2005, 218). When transposed into the legislative process, there is evidence that the 'ground rules' are contributing to 'classic Executive dominance in Scotland that could be used to support the arguments of the 'old politics' camp' (Shephard and Cairney, 2004, 854).7 In November 2005 the Scottish political editor of The Herald observed that 'quietly in the background something is going badly wrong with parliament legislation' (The Herald, 15 November 2005). What was happening was that the rights of ordinary MSPs to introduce 'non-executive bills' were being curtailed. Similarly, the over-optimistic predevolution consensus, which envisaged a 'more active legislature which directed the budget as part of a 'new politics"' (Midwinter, 2005, 28), was inhibited by the inheritance of 'a classic incremental budgetary system from Westminster in which parliamentary scrutiny was minimal' (ibid., 13). 
One further inheritance of 'old politics' was reflected in the press coverage afforded to the new parliament. A persistent theme of press reporting has been the uncovering of 'scandals' in parliament and the executive - most of which were trivial in their own right but generated significant coverage. As Keating $(2005,93)$ observes, there has also been an 'almost universal tendency to describe devolution as a disappointment and a failure'. From the outset the issue of the new parliament building contributed to this sense of failure and plagued the new parliament throughout its first four-year term, as the costs spiralled from an initial estimate of $\mathrm{d} 40$ million to over $\mathrm{d} 430$ million by the time the building was officially opened in October 2004. For many in the Scottish media the intricacies of the architectural design and subsequent problems with construction on the Holyrood site served as a metaphor of the inherent deficiencies of the devolution project itself. The political inhabitants of the building were also subject to withering scrutiny, with MSPs widely dismissed as political pygmies or second-rate politicians. This concern with individuals rather than issues and with scandals rather than serious debate was epitomised in the circumstances leading to the resignation of the Conservative party leader David McLetchie in November 2005. Academics and journalists alike voiced concern that the use of FOI requests for taxi receipts had 'trivialized Holyrood and demonized MSPs' (Sunday Herald, 6 November 2005; also see Ruaridh Nicoll, The Guardian, Media, 6 November 2005).

If one of the objectives of devolution was to reverse an apparent decline in both popular trust and confidence in the political process in Scotland and to increase electoral participation then 'devolution has not helped to reconnect the public with the way they are governedy it simply has not made much difference one way or the other' (Curtice, 2004, 233). Moreover, focus group research conducted for the Arbuthnott Commission $(2006,69)$ found that, even after the introduction of the Scottish parliament, there remained 'a deep distrust amongst many citizens, particularly younger ones, of established politics and the relevance of voting'. Generally, the Commission found high levels of political disengagement and cynicism. Indeed, there was the irony that research, undertaken on behalf of the Commission, found: 'there was a widespread assumption amongst those interviewed that the MP [rather than the MSP] is the most important representative for their area' (George Street Research, 2005, ii).

\section{Local government}

If the 'third way' vision is clear - that there should be 'experiments with democracy' (Giddens, 1998, 775) to re-establish contacts between citizens and government - then, given that local government accounts for approximately 80 per cent of state-citizen contacts annually (Stoker, 2002, 422), localities 
would appear to be the obvious place to focus these experiments. Unquestionably, New Labour in power has actively pursued a 'radical programme of democratic renewal' (Wilson and Game, 2002, 354).8 This 'modernisation' programme has included: new modes of citizen consultation and engagement (through citizens' juries; focus groups, citizens' panels, deliberative opinion polls, and local referendums); modernisation of electoral arrangements (through the adoption of PR in Scottish local authorities; all postal vote ballots, electronic voting and counting, and e-democracy initiatives); and modernisation of council organisational structures (through elected mayors, cabinet models, and local strategic partnerships). The actual impact of these initiatives, however, is open to dispute; as what is far from clear is the extent to which any of these initiatives 'offer participants a meaningful route to making a difference to the ultimate outcome' (Sullivan, 2004, 195). Leaving aside an evaluation of the actual enhancement of local democracy since 1997 (for sceptical reviews see for example Lownes and Wilson, 2003; Sullivan et al., 2004; Dinham, 2005), the true significance of the 'local experiments' with democracy is that they were conducted at all by a New Labour government accused of 'control freakery gone mad' (Stoker, 2002, 430).

One explanation is that the discourse of local modernisation simply 'provided a convenient smokescreen for Labour's centralising and hence authoritarian tendencies: it gave the excuse to tell local authorities what to do' (Coulson, 2004, 472). But this overstates the case, as New Labour had a clear vision of the value of democratisation that was not to be obscured by any such 'smokescreen'. A more considered analysis would direct attention to the possibility that democratic renewal was about restoring trust and confidence in local democracy and especially local representative institutions. In this sense 'local democracy referred to the quality of the relationship between local authorities and their communities and service users - and not the degree of autonomy or level of capacity enjoyed by elected councils' (Lowndes and Wilson, 2003, 290). This point is neatly captured in Wilson and Game's (2002, 353) observation that:

Led by Deputy Prime Minister and Environment Secretary John Prescott, ministers were keen from the outset to emphasise their genuine belief in and commitment to a strong, democratically elected local government. Things would be very different under Labour but they, as ministers in a popularly elected national government, would be the ones deciding just how different things would be.

Conforming to a power dependency model of central-local relations, New Labour in government did not seek to reduce its capacity to formulate and drive through its local initiatives. In this regard it retained a 'top down, rule 
bound, control orientation' (Stoker, 2002, 430). Yet, from this centralist orientation or perspective, where its own scope for policy discretion was secure, New Labour displayed a clear 'peripheral vision' of the need for bottom-up processes of democratisation at the local level.

This bottom-up perspective has also been apparent in a range of decentralized, participatory initiatives in the provision of other public services. One of the most visible was the Department of Health's Your Health, Your Care, Your Say consultative process which preceded the drafting of the 2006 White Paper Our Health, Our Care, Our Say (Cm6737). In the autumn of 2005, four regional deliberative forums were convened - billed as 'listening events' - to enable local people to discuss the future of the health and social care services. The consultation process culminated in a 'Citizen's Summit' in Birmingham on 29 October 2005. At this 'summit' 998 people, drawn from across England, met to discuss and vote on a range of options about the priorities, choices and type of health and care provision in the early $21 \mathrm{st}$ century. As such it was the 'biggest public consultation of its kind ever held in Britain'. While participants were selected to reflect a cross section of the population, special effort was made to 'make sure that the views of people who don't always get involved in this kind of consultation were heard' (see www.dh.gov.uk/assetRoot/04/12/27/68/04122768.pdf).

Ultimately, however, the real test of such processes remains that: 'participation and inclusion are only meaningful if people's views can be seen to make a difference and to influence the development of policy' (HcHugh and Parvin, 2005, 15). In an effort to 'pass' this test, Health ministers met in March 2006 with 100 participants who had attended the original deliberative events in order to explain the policies outlined in the White Paper. This follow-up event was entitled 'Holding the Government to Account'. Ministers took this opportunity to 'present how the Government had included many of the suggestions made by the public during the 2005 listening events' (www.dh. gov.uk/NewsHome/YourHealthYourCareYourSay/YourSayArticle/fs/en? CONTENT_ID $=4131703 \&$ chk=tDPIyT). Equally, in the White Paper itself, ministers also took the opportunity to explain why the views of participants had not been accepted on some important issues (see Cm 6737, 2006, paras 2.28, 8.13).

\section{Connected Blind Spot and Peripheral Vision: Electoral Reform}

Nowhere is the connection between New Labour's central democratic blind spot and its clear participatory peripheral vision better illustrated than in the view of electoral reform adopted by governments since 1997.

In November 2005 an Electoral Choice Bill was introduced, as a 10minute Rule Bill in the House of Commons, by Labour MPs John Denham and David 
Chaytor and by the Liberal Democrat MP Nick Harvey. With no hope of translation into legislation, the Bill was designed to publicise the failure of New Labour to reform the system for Westminster elections and to suggest mechanisms whereby a referendum on electoral reform could be prompted without having to wait for the government to call such a referendum. Despite manifesto pledges in 1997 and 2001 to hold a referendum and to revisit this issue after a review of the operation of non-Westminster electoral systems, New Labour in power had managed to obscure electoral reform from its central vision. Indeed, as Kavanagh et al. note (2006, 399-400): 'As of 2006, PR is effectively off the agenda and there is little prospect of a referendum in the near future. [Many New Labour ministers still calculate that the established electoral arrangements, a key part of the traditional Westminster system and its underpinning elitism, still operates in their interests'.

In essence, however, this 'calculation' was restricted to the centre; for, in its peripheral vision, New Labour was more than willing to identify the democratic case for electoral reform and to experiment with a variety of different systems (even if implementation of such reform reflected more expedient partisan concerns). Elections to the European Parliament are based upon a regional list system with counting by the d'Hondt method. The Scottish Parliament, the Welsh National Assembly, and the Greater London Authority are elected under the Additional Member System (with different proportions of list members in each institution); the single transferable vote (STV) is used in all elections in Northern Ireland except those for Westminster; from 2007 local authority elections in Scotland will be conducted by STV; and Mayoral elections in England use the Supplementary Vote system. Far from being 'blind' to the virtues of electoral reform, therefore, New Labour has possessed an extensive vision, some would argue too wide-ranging a vision, in its implementation of a raft of diverse electoral systems.

The fact that Scotland alone had four different systems in operation in 2006 not only revealed the reality of 'multi-level governance' but also reflected the complexities attendant upon the asymmetric and piecemeal implementation of voting reforms. Indeed, concern over these complexities and asymmetries led to the appointment of the Arbuthnott Commission in May 2004 to consider the impact of the multiplicity of voting systems and differences in constituency boundaries upon voter participation. While the Commission's final report found no evidence that multiple voting systems or different boundaries confused voters to the extent of deterring electoral involvement (Arbuthnott Commission, 2006, para 2.18), it did find considerable ignorance of all voting systems apart from first-past-the-post. Yet the Commission concluded that the 'case for introducing a more proportional system fory[Westminster] elections is now very strong, since after 2007 they will be the only ones held in Scotland which do not involve a significant degree of proportionality' (ibid., para 2.17). 
Yet, if there is no direct correlation between voting system and turnout given that voters tend to be equally ignorant of the mechanics of all systems apart from the first-past-the-post — then New Labour might feel justified in arguing that the focus of attention for Westminster elections should be upon encouraging electors to cast their vote in the first place rather than upon the technical processes by which votes were counted. Certainly New Labour had no doubts that 'it is the role of Government to be concerned about the condition of our democracy' (Harman, 2006). Indeed, given the historically low turnouts at the 2001 and 2005 general elections in the UK, the government could hardly be anything other than 'concerned' about democracy in the UK. The view of New Labour in government as to "what democracy should look like' was that democratic legitimacy was based upon three electoral propositions: 'everyone who is eligible to vote having the right to vote; people who are entitled to vote actually wanting to vote; and no one fiddling the vote' (ibid.). These principles found legislative form in the Representation of the People Act 2000, which allowed voters to request a postal vote in any statutory election in Britain and enabled local authorities to pilot schemes for electoral arrangements, most importantly for all postal ballots. The European Parliamentary and Local Elections (Pilots) Act 2004 sanctioned further pilots in four regions in the combined European and local government elections on 10 June 2004. More broadly, the Electoral Administration Act 2006 sought, amongst other things, to improve the electoral registration process, enhance information and publicity about the elections, ease access to voting stations, provide stronger deterrents for electoral fraud, improve the effectiveness of the administration of elections, enhance participation through reducing the age of candidacy from 21 to 18 , and simplify the rules for candidates and political parties.

New Labour's concern with electoral processes also found institutional form in the creation of the Electoral Commission in November 2000. Under the Political Parties, Elections and Referendums Act 2000 the Commission was charged with keeping electoral law and practice under review, as well as monitoring and evaluating local election pilot schemes, and increasing understanding of, and participation in, the democratic process. The Commission was also required to report on the administration of all major elections. As part of this reporting exercise, the Commission has paid particular attention to the issue of turnout and the specific theme of the electoral disengagement of young people (see Electoral Commission, 2002, 2005, 2006).

Alongside this institutional commitment to the enhancement of electoral democracy New Labour has also been keenly aware of the fact that: 'Our democracy lacks legitimacy if, whatever the formal rules about universal suffrage and the right to vote, people don't make it a reality by turning out to vote' (Harman, 2006). What was of particular concern was the development of 
'democracy deserts' in certain areas of the UK; where the problems of social exclusion were compounded by low levels of democratic engagement as manifested in low levels of registration and low levels of turnout. The dilemma highlighted in these areas was that the citizens who were most dependent on the state, and were most directly affected by redistributive policies, were precisely those who were least likely to be engaged in the electoral and other participatory processes.

\section{Conclusion}

The purpose of this article has been to review the democratic vision of New Labour in government since 1997. Many critics would argue that this is a futile task as the projection of such a vision has not been part of the New Labour project and, in fact, successive Blair governments have served to undermine the historic image of representative democracy in the UK (see Norton, 2004, 544). But this is not the conclusion reached here. Indeed, if New Labour warrants criticismit is not for failing to have a vision of where it is going but rather of having two distinct visions of democracy that coexist in an uneasy, and often paradoxical, relationship. The contention of this article has been that New Labour in government has displayed, on the one side, an orthodox, centralized vision encapsulated in the 'Westminster model'; yet, on the other, has simultaneously projected a 'third way' image based on a 'deepening and widening of democracy'; of 'enabling government'; and of 'double devolution' (Giddens, 1998; Miliband, 2006). In the eyes of many of New Labour's critics this is a 'rose-tinted' peripheral vision, one that fails to compensate for the central blindspot of the Westminster vision (see Morrison, 2001, 501), and one that raises questions about the compatibility of indirect/representative and direct/participatory democratic principles and practice. As a result, governments since 1997 have displayed the classic symptoms of institutional macular degeneration: with a blind spot at the centre (Westminster) yet with clear peripheral vision (both in terms of decentralisation and participation beyond Westminster).

What is striking is that, after almost a decade in power, the Westminster model is still at the centre of the government's democratic vision. Despite a period of perpetual constitutional reform, and persistent challenges to the practice of Westminster-based politics, the verdict remains that: 'New Labour's constitutional project cannot be interpreted as a fundamental paradigm shift' (Flinders, 2005, 87). The failure to make this 'shift' has variously been ascribed to a paucity of intellect, an absence of joined-up thinking, and an unwillingness to conceive of an 'alternative constitution' (see Smith, 2003, 591-593; Flinders, 2004, 143; Johnson, 2004, 308-309). Yet such criticisms do raise a fundamental question about what can realistically be expected of New Labour, or any party 
in government, to fashion an 'alternative' democratic vision. For, as argued elsewhere (Judge, 2005, 277-279), the Westminster model still symbolises the elemental values of representation and accountability that serve as the prescriptions of legitimate government in the UK. The Westminster model retains its significance as an organising perspective in the sense of identifying a set of norms, values and meanings that legitimate the actions and interactions of state institutions. These might very well be idealised - in their specification of a serial flow of legitimacy from the people through their elected representatives to an accountable and responsive executive. Nonetheless, these values and their institutional embodiment remain the 'stem cell' of modern UK government.

More particularly this model 'clearly distinguishes between participation and decision-making, and applies different rules to each it does [not] confuse the notion of fair consultation and participation with fair decision-making procedures' (McHugh and Parvin, 2005, 17). In fact, the distinctiveness of parliamentary representation is hermetically sealed in the Westminster model in the notion of parliamentary sovereignty - which privileges representation based upon UK parliamentary elections above all other forms of representation and popular participation. This has been the central vision of all governments in the era of the mass franchise. This has also been the vision that has been obscured in the practice of 'executive sovereignty' and which has displayed the symptoms of 'macular degeneration'.

What critics of the Westminster model tend to focus upon, therefore, is not the model itself but the challenges posed by 'governance' to the model, or the political practices that have been associated with the model: the accretion of power to the executive, the closed and exclusionary processes of decision making in the core executive, and the inversion of accountability. What New Labour has been reluctant to contemplate is the restitution of the democratic principles of the model, not least because the model has always been an idealised representation of parliamentary government (see Birch, 1964, 65, 74). As a result, redress of the democratic imbalances and inversions of accountability between parliament and the executive have largely been blanked from the reformist vision of New Labour in government. The mutually reinforcing norms - of party cohesion, party discipline, partisan risk-aversion, pathological antipathy to media criticism, collective notions of executive responsibility, closed and restricted modes of decision making — provide for the incubation of macular degeneration.

The historic problem in the UK has been how to envisage such a rebalancing between legislature and executive given the blind spot at the centre of successive governments' institutional vision. The fundamental challenge has been, and remains, how to overcome the conundrum that the 'dominant value system' - executive hegemony - at the heart of the practice of the 
Westminster model needs to be redressed by executive action itself. New Labour, to date, in common with all of its post-war predecessors in government, has failed to address this conundrum. Yet, for those readers in need of a 'happy ending', the period since 1997 has also witnessed the strengthening of potential 'normative subsystems' — of 'deviant subcultures' - which have challenged leadership policies and been prepared to infringe the norms of party discipline and voting cohesion in Westminster. In essence, these subcultures have emphasised collective (parliamentary) processes rather than majoritarian (executive) processes of decision-making. At their root these subcultures have a vision of representative processes focused beyond the executive, and provide, in essence, an 'oppositional' vision (whether of the formal opposition parties in Westminster, or of the 'informal opposition' provided by 'rebels' within the Labour party itself, or of campaigning organisations beyond Westminster). These subcultures value effective representation, seek a rebalancing of executive and legislative power, and recognize that the stranglehold of conjoined party and executive leadership positions needs to be broken - either through a concordat between the legislature and the executive (see Power Inquiry, 2006, 135-138); or more radically by electoral reformat Westminster (see Wright, 2004, 875; Labour Campaign for Electoral Reform, 2005); or more radically still through a formal separation of powers in a written constitution (see Allen, 2003, 70; Wright, 2004, 875). The challenge is how to enable such a rebalancing between legislature and executive before the symptoms of macular degeneration afflict future majority party leaders on entering government in Westminster.9

\footnotetext{
Notes

1 The macular is the central part of the retina that is responsible for central vision and the ability to see in detail. Macular degeneration affects this central part of the retina and results in localised vision loss - so generating a blind spot at the centre of vision, but without affecting peripheral vision.

2 In the draft new Civil Service Code this instruction was pared down to: 'You must not: disclose official information without authority' (Cabinet Office, 2006, para 5).

3 Lord Birt did eventually appear before the Public Administration Committee in April 2006, after he had left his position as the PM's Strategy Adviser. As Tony Wright, Chairman of the Committee observed, 'It has been lovely to see you. The sky would not have fallen in had you come to us when you were still in office. The sky will not fall in because you have come to us now' (HC 756-iii, 2006, Q356). In his evidence Lord Birt stuck rigidly to the Cabinet Office rules: 'I am very happy to talk to the Committee about the sorts of issues that have been raised so far, namely the way in which government structures itself to address strategic questions, but I am afraid I do not want to go into any of the detail of my advice to the Prime Minister or the response to that advice' (HC 756-iii, 2006, Q259).

4 Notably the types of information requested by sections of the tabloid press included the number of windows at the Department of Education and Skills, the amount of money spent by departments on toilet paper, the cost of the PM's make-up since 1999, and the PM's guest list at
} 
Chequers. In response, Lord Falconer pledged to review the operation of the Act to curb 'the wilder fevers of journalist wish-lists' (The Guardian, 31 December 2005).

5 In rapid succession New Labour introduced the Terrorism Act 2000, the Anti-Terrorism, Crime and Security Act 2001, the Prevention of TerrorismAct 2005, and the Terrorism Act 2006. Each legislative measure contained, in Amnesty International's opinion, 'provisions which are clearly incompatible with human rights law and standards and have given rise to serious human rights violations' (HL75-ii/HC 561-ii, 2005, Ev 70). In addition, the Immigration, Asylum and Nationality Act 2006 and the Identity Cards Act 2006, both of which formed part of the government's counter-terrorism strategy, attracted wide-ranging criticism from human rights groups.

6 The focus here is upon Scottish governance. On Wales and Northern Ireland see Judge 2005.

7 Shephard and Cairney's findings reveal the complexity and contingency of relationships between the legislature and the executive in Scotland. They also present evidence of 'powersharing' and support for the 'new politics camp'.

8 The focus of the following discussion is upon English local government. On local government and devolution see McConnell, 2004; Judge, 2005; Jeffery, 2006.

9 The last sentence of an article is perhaps an inappropriate place for speculation. If, however, macular degeneration is associated with 'insider' status and holding conjoined party, legislative and executive leadership positions, the conundrumis how to inoculate 'outsiders', in the transition into executive office, fromthe pathologies of executivementality. In other words, how is an 'outsider', oppositional perspective on the relationship between legislature and executive to be retained? In this sense, the fate of electoral reformfor Westminster elections is one critical test for macular degeneration; and it is a test that has produced negative results from successive governments. Yet, Gordon Brown - after the 2005 election, in his position as heir-apparent to Tony Blair and PM-in-waiting (and also 'outsider' to the Blair cabal) - expressed his desire to shape a future constitutional settlement around a 'compact between the local and the national, and between the executive and the legislature' (The Guardian, 27 February 2006). In preparation for this settlement $\mathrm{Mr}$ Brown countenanced a 'renewed debate on issues from the role of parties and electoral reform'. Brown's positioning as an 'outsider' within the executive may prove decisive in reducing the size of the institutional blind spot should he become PM. Alternatively, in the event of David Cameron becoming prime minister, there is some indication that the dominance of the executive and the adversarial nature of party competition would at least be recognised as inhibitions on democratic advance. In December 2005, Mr Cameron created a 'Democracy Task Force' (www.conservatives.com/tile.do?def1/4democracy.taskforce.page). In June 2006, in a speech to the Power Inquiry Conference, he acknowledged that:

'Consensus can be a good thing'. He went on to state: 'I want to put Parliament at the centre of national life. I want to address the shift away from the legislature to the executive. We must remove the power of the executive to ride roughshod over the legislature' (www.conservatives.com/tile.do?def1/4news.story.page\&obj_id1/4129626).

\section{References}

Allen, G. (2003) The Last Prime Minister: Being Honest About the UK Presidency, Exeter: Imprint Academic.

Arbuthnott Commission (2006) Putting Citizens First: Boundaries, Voting and Representation in Scotland, Commission on Boundary Differences and Voting Systems. Edinburgh: The Stationery Office. 
Arter, D. (2003) The Scottish Parliament and the Goal of a 'New Politics': A Verdict on the First Four Years. Working Paper ECPR Standing Group on Parliaments, Essex: ECPR, (available at www.essex.ac.uk/ecpr/standinggroups/parliaments/papers/arter.pdf).

Aspinwall, M. (2004) Rethinking Britain and Europe: Plurality Elections, Party Management and British Policy on European Integration, Manchester: Manchester University Press.

Bartle, J. (2005) 'The Labour Government and the Media', in J. Bartle and A. King (eds.) Britain at the Polls 2005, Washington D.C.: CQ Press.

Birch, A.H. (1964) Representative and Responsible Government, London: Allen and Unwin.

Blair, T. ([1998] 2003) 'The Third Way: New Politics for the New Century', in A. Chadwick and R. Heffernan (eds.) The New Labour Reader, Cambridge: Polity Press.

Bogdanor (2003) 'Introduction', in V. Bogdanor (ed.) The British Constitution in the Twentieth Century, Oxford: British Academy/Oxford University Press.

Bonney, N. (2003) 'The Scottish Parliament and Participatory Democracy: Vision and Reality', Political Quarterly 74(4): 459-467.

Bradbury, J. and Mitchell, J. (2005) 'Devolution: Between Governance and Territorial Politics', Parliamentary Affairs 58(2): 287-302.

Brazier, A., Finders, M. and McHugh, D. (2005) New Politics, New Parliament? A Review of Parliamentary Modernisation Since 1997, London: Hansard Society.

Cabinet Office (1999) The Civil Service Code, London: Cabinet Office, (available at www. cabinetoffice.gov.uk/propriety_and_ethics/civil_service/civil_service_code.asp).

Cabinet Office (2005a) Ministerial Code: A Code of Ethics and Procedural Guidance for Ministers, London: Cabinet Office, (available at www.cabinet-office.gov.uk).

Cabinet Office (2005b) Departmental Evidence and Response to Select Committees, London: Cabinet Office, (available at www.cabinet-office.gov.uk).

Cabinet Office (2006) Civil Service Code, London: Cabinet Office, (available at www.civilservice. gov.uk/publications/pdf/CSCodeOfConduct.pdf).

Cm5291 (2001) The House of Lords: Completing the Reform, London: The Stationery Office.

Cm6737 (2006) Our Health, Our Care, Our Say: A New Direction for Community Services, Department of Health, London: The Stationery Office.

Cmnd 5104 (1972) Report of the Departmental Committee on Section 2 of the Official Secrets Act 1911, London: HMSO.

Conservative Party (2005) Are You Thinking What We're Thinking? It's Time For Action, Conservative Party Manifesto 2005, London: Conservative Party.

Cook, R. (2003) The Point of Departure, London, Simon \& Schuster.

Coulson, A. (2004) 'Local Politics, Central Power: The Future of Representative Local Government in England', Local Government Studies 30(4): 467-480.

Cowley, P. (2002) Revolts and Rebellions: Parliamentary Voting Under Blair, London: Politico's.

Cowley, P. (2005) The Rebels: How Blair Mislaid His Majority, London: Politico's.

Curtice, J. (2004) 'Restoring Confidence and Legitimacy? Devolution and Public Opinion', in A. Trench (ed.) Has Devolution Made a Difference, Exeter: Imprint Academic.

Department of Constitutional Affairs (2006) Freedom of Information Act: Statistics on Implementation in Central Government. Q4 October-December 2005, London: Department of Constitutional Affairs.

Dinham, A. (2005) 'Empowered or Overpowered? The Real Experiences of Local Participation', Community Development Journal 40(3): 301-312.

Electoral Commission (2002) Voter Engagement and Young People, London: The Electoral Commission.

Electoral Commission (2005) Election 2005: Turnout. How Many, Who and Why? London: The Electoral Commission.

Electoral Commission (2006) An Audit of Political Engagement 3, Research Report March 2006, London: The Electoral Commission and the Hansard Society.

Evans, M. (2003) Constitution-Making and the Labour Party, London: Palgrave Macmillan.

Ewing, K.D. (1999) 'The Human Rights Act and Parliamentary Democracy', The Modern Law 
Review 62(1): 79-99.

Finer, S.E. (1975) 'Adversary Politics and Electoral Reform', in S.E. Finer (ed.) Adversary Politics and Electoral Reform, London: Antony Wigram.

Flinders, M. (2002) 'Shifting the Balance? Parliament, the Executive and the British Constitution', Political Studies 50(1): 23-42.

Flinders, M. (2004) 'New Labour and the Constitution', in S. Ludlamand M.J. Smith (eds.) Governing as New Labour: Politics and Policy Under Blair, London: Palgrave Macmillan.

Flinders, M. (2005) 'Majoritarian Democracy in Britain: New Labour and the Constitution', West European Politics 28(1): 61-93.

George Street Research (2005) Commission on Boundary Differences and Voting Systems: Final Report, Edinburgh: George Street Research Ltd.

Giddens, A. (1998) The Third Way: The Renewal of Social Democracy, Cambridge: Polity.

Giddens, A. (2000) The Third Way and its Critics, Cambridge, Polity.

Hailsham, Lord (1978) The Dilemma of Democracy, Glasgow: Collins.

Harman, H. (2006) A New Deal for Democracy, Speech to the Hansard Society 16 January 2006, (available at www.dca.gov.uk/speeches/2006/sp060116.htm).

HC 136 (2002) Ministerial Accountability and Parliamentary Questions: The Government Response to the Committee's Ninth Report of Session 2001-2002, First Report, Public Administration Committee, Session 2002-2003, House of Commons. London: The Stationery Office.

HC 300 (2000) Shifting the Balance: Select Committees and the Executive, First Report, Liaison Committee, Session 1999-2000, House of Commons, London: The Stationery Office.

HC 446 (2004) Annual Report for 2003, Liaison Committee, Session 2003-2004, House of Commons. London: The Stationery Office.

HC 690 (2005) The Attendance of the Prime Minister's Strategy Adviser before the Public Administration Select Committee, Public Administration Select Committee, First Special Report Session 2005-2006. London: The Stationery Office.

HC 709-i (2005) The Prime Minister: Oral Evidence given by Rt Hon Tony Blair MP, 22 November 2005, Liaison Committee, Session 2005-2006. London: The Stationery Office.

HC 756-iii (2006) Governing the Future, Lord Birt, Minutes of Evidence, 20 April 2006, Public Administration Select Committee, Session 2005-2006. London: The Stationery Office.

HC 1180-i (2004) Evidence to Committees: Oral Evidence given by Rt Hon Peter Hain MP, 19 October 2004, Liaison Committee, Session 2003-2004. London: The Stationery Office.

HL75-ii/HC 561-ii (2005) Counter-Terrorism Policy and Human Rights: Terrorism Bill and Related Matters, House of Lords, House of Commons Joint Committee on Human Rights, Third Report, Session 2005-2006. London: The Stationery Office.

House of Commons (2005a) Modernisation of the House of Commons 1997-2005, House of Commons Library Research Paper 05/46. London: House of Commons.

House of Commons (2005b) Freedom of Information Requests, House of Commons Library Standard Note, SN/PC/2950. London: House of Commons.

Jeffery, C. (2006) 'Devolution and Local Government', Publius: The Journal of Federalism 36(1): 5773.

Johnson, N. (2004) Reshaping the British Constitution: Essays in Political Interpretation, London: Palgrave Macmillan.

Judge, D. (1981) Backbench Specialisation in the House of Commons, London, Heinemann

Educational Books. 
Judge, D. (1983) 'Considerations on Reform', in D. Judge (ed.) The Politics of Parliamentary Reform, London: Heinemann Educational Books.

Judge, D. (1990) Parliament and Industry, Aldershot: Dartmouth.

Judge, D. (1993) The Parliamentary State, London: Sage.

Judge, D. (2005) Political Institutions in the United Kingdom, Oxford: Oxford University Press.

Kavanagh, D., Richards, D., Smith, M. and Geddes, A. (2006) British Politics (5th edn.). Oxford: Oxford University Press.

Keating, M. (2005) The Government of Scotland: Public Policy Making After Devolution, Edinburgh: Edinburgh University Press.

Kelso, A. (2006) 'The House of Commons Modernisation Committee: Who Needs It?' British Journal of Politics and International Relations, forthcoming.

Labour Campaign for Electoral Reform (2005) LCER Guide to the General Election 2005, (available at www.electoralreform.connectfree.co.uk/).

Labour Party (1997) New Labour: Because Britain Deserves Better, London: Labour Party.

Labour Party (2001) Ambitions for Britain, Labour's Manifesto 2001, London: Labour Party.

Labour Party (2005) Britain: Forward not Back, Labour's Manifesto 2005, London: Labour Party.

Low, S. (1904) The Governance of England, London: Fischer Unwin.

Lownes, V. and Wilson, D. (2003) 'Balancing Revisability and Robustness? A New Institutionalist Perspective on Local Government Modernization', Public Administration 81(2): 275-298.

Ludlam, S. (2004) 'Introduction: Second Term New Labour', in S. Ludlam and M.J. Smith (eds.) Governing as New Labour: Politics and Policy Under Blair, London: Palgrave Macmillan.

Mandelson, P. and Liddle, R. (1996) The Blair Revolution: Can New Labour Deliver? London: Faber and Faber.

McConnell, A. (2004) Scottish Local Government, Edinburgh: Edinburgh University Press.

McHugh, D. and Parvin, P. (2005) Neglecting Democracy, London: Hansard Society.

Midwinter, A. (2005) 'Budgetary Scrutiny in the Scottish Parliament: An Advisers View', Financial Accountability and Management 21(1): 13-32.

Miliband, D. (2006) 'Speech by the Minister of Communities and Local Government at the National Council of Voluntary Organisations' Annual Conference', Empowerment Not Abandonment, 21 February 2006, (available at www.odpm.gov.uk/index.asp?id=1163772).

Mitchell, J. (2004) 'Scotland: Expectations, Policy Types and Devolution', in A. Trench (ed.) Has Devolution Made a Difference? The State of the Nations 2004, Exeter: Imprint Academic.

Mitchell, J. (2005) 'Scotland: Devolution is Not Just for Christmas', in A. Trench (ed.) The Dynamics of Devolution: The State of the Nations 2005, Exeter: Imprint Academic.

Morrison, J. (2001) Reforming Britain: New Labour New Constitution? London: Reuters.

Oliver, D. (2003) Constitutional Reform in the UK, Oxford: Oxford University Press.

Power Inquiry (2006) Power to the People. The Report of Power: An Independent Inquiry into Britain's Democracy, (available at www.powerinquiry.org).

Quinn, T. (2004) Modernising the Labour Party: Organisational Change Since 1983, Basingstoke: Palgrave Macmillan.

Radcliffe, J. (1991) The Reorganisation of British Central Government, Aldershot: Dartmouth.

Rush, M. (2001) The Role of the Member of Parliament Since 1868: From Gentleman to Players, Oxford: Oxford University Press.

Russell, M. (2005) Building New Labour: The Politics of Party Organisation, Basingstoke: Palgrave Macmillan.

Searing, D.D. (1994) Westminster's World, Cambridge, MA: Harvard University Press.

Shaw, E. (2004) 'The Control Freaks? New Labour and the Party', in S. Ludlam and M. J. Smith (eds.) Governing as New Labour, Basingstoke: Palgrave Macmillan.

Shephard, M. and Cairney, P. (2004) 'Consensual or Dominant Relationships with Parliament? A Comparison of Administrations and Ministers in Scotland', Public Administration 82(4): 831855. 
Smith, T. (2003) ' "Something Old, Something New, Something Borrowed, Something Blue': Themes of Tony Blair and His Government', Parliamentary Affairs 56(4): 580-597.

Stevens, R. (2002) The English Judges: Their Role in the Changing Constitution, Oxford: Hart Publishing.

Stoker, G. (2002) 'Life is a Lottery: New Labour's Strategy for the Reform of Devolved Governance', Public Administration 80(3): 417-434.

Sullivan, H. (2004) 'Community Governance and Local Government: A Shoe that Fits or the Emperor's New Clothes?', in G. Stoker and D. Wilson (eds.) British Local Government into the 21st Century, Basingstoke: Palgrave Macmillan.

Sullivan, H., Knopps, A., Barnes, M. and Newman, J. (2004) 'Central-Local Relations in an Era of Multi-Level Governance: The Case of Public Participation Policy in England, 1997-2001', Local Government Studies 30(2): 245-265.

Trench, A. (2004) 'Introduction: Has Devolution Made a Difference', in A. Trench (ed.) Has Devolution Made a Difference, Exeter: Imprint Academic.

Weir, S. and Beetham, D. (1999) Political Power and Democratic Control in Britain, London: Routledge.

Wilson, D. and Game, C. (2002) Local Government in the United Kingdom, (3rd edn.) London: Palgrave Macmillan.

Wright, T. (1994) Citizens and Subjects: An Essay on British Politics, London: Routledge.

Wright, T. (2004) 'Prospects for Parliamentary Reform', Parliamentary Affairs 57(4): 867-876. 